\title{
Finite Element Analysis of Cold Formed Steel Channel Columns with Complex Edge Stiffeners and Web Holes using Abaqus
}

\author{
M. Hemapriya, T.P. Meikandaan, Maharajothi. R
}

\begin{abstract}
The present theory work means to think about the numerical examination on models of channel segment with middle and complex edge stiffeners and web gaps under pivotal pressure. A wide scope of parameters, for example, slimness proportion, spine width and thickness have been considered in the investigation. An aggregate of 12 channel models with various parameters, for example, length, thickness and rib width are reenacted. The limited component non-direct examination program ABAQUS V6.14-2 is utilized to reproduce the models. The material properties are acquired from Coupon test. Component type utilized in this non-straight examination is SHELL. A Static, Riks step is utilized to complete examination. The Failure modes, extreme burden and the pressure conveyance around web gaps are inquired about. The relocation parts in every augmentation of burden along $X, Y$ and $Z$ bearings and Rotation segment about $X$ course are gathered. The Von-Mises pressure forms, Deformed shapes and disappointment modes including nearby, horizontal distortional and parallel torsional clasping modes are acquired. The pivotal burden limits of pressure individuals with various parameters are looked at.
\end{abstract}

Key words: Cold Formed Steel(CFS),Coupon Test,ABAQUS, Modelling,Buckling Analysis..

\section{INTRODUCTION}

Cold-Formed steel (CFS) auxiliary areas, less recognizable yet of developing significance, Cold-shaped steel individuals are ordinarily utilized as purlins, cladding rails, sheeting rails, divider studs, floor joists, sheets and decks, and so on. When contrasted and thicker hot moved individuals they give a significant increment in solidarity to weight proportion. Slim sheet steel items are broadly utilized in building industry, and range from purlins to rooftop sheeting and floor decking. By and large these are accessible for use as essential structure components for gathering at site or as pre-assembled casings or boards. These flimsy steel areas are cold-shaped, for

Revised Manuscript Received on October 22, 2019.

M. Hemapriya Assistant Professor, Department Of Civil Engineering,,Bharath Institution Of Higher Education And Research,TamilNadu, India Email: meihemapriya@gmail.com

T.P. Meikandaan, Associate Professor, Department Of Civil Engineering,,Bharath Institution Of Higher Education And Research,TamilNadu, India.Email: ganga_meik@yahoo.co.in

Maharajothi. R Student,Department Of Civil Engineering,,Bharath Institution Of Higher Education And Research,TamilNadu, India Email: example their assembling procedure includes shaping steel segments in a virus state (for example without use of warmth) from steel sheets of uniform thickness. The thickness of steel sheet utilized in cool shaped development is typically 1 to 3 $\mathrm{mm}$. A lot thicker material up to $8 \mathrm{~mm}$ can be shaped if pre-excited material isn't required for the specific application. The strategy for assembling is significant as it separates these items from hot moved steel areas. Typically, the yield quality of steel sheets utilized in cool shaped segments is at any rate $280 \mathrm{~N} / \mathrm{mm} 2$. ABAQUS is an industrially accessible limited component investigation programming bundle for FEA. It is a universally useful Finite Element Modeling Package for numerically taking care of an assortment of mechanical issues. The program contains numerous extraordinary highlights which enable nonlinearities or auxiliary impacts to be remembered for the arrangement, for example, pliancy, enormous strain, hyper versatility, creep, expanding, huge redirections, material anisotropy and radiation. The limited component program of ABAQUS 6.14-2 adaptation is utilized to build up the limited component model, which planned to reproduce the conduct of cold shaped pressure individuals with web openings.[1]-[5]

\section{ABAQUS PROGRAMME}

ABAQUS is an industrially accessible limited component examination programming bundle for FEA. These issues incorporate static and dynamic auxiliary investigation (both direct and nonlinear), unfaltering state and transient issues, mode recurrence and clasping examinations, acoustic and electromagnetic issues and different sorts of field and coupled-field applications. A Graphical User Interface (GUI) is accessible all through the program, to direct new clients through the learning procedure and give progressively experienced clients numerous windows, pull-down menus, exchange boxes, apparatus bars and on-line documentation. Abaqus contains a broad library of components that can display for all intents and purposes any geometry.[6]-[10] Abaqus offers a wide scope of capacities for reenactment of straight and nonlinear applications. Issues with numerous parts are displayed by partner the geometry characterizing 
every segment with the fitting material models and indicating segment communications. In a nonlinear investigation Abaqus consequently picks fitting burden augmentations and assembly resistances and consistently alters them during the examination to guarantee that an exact arrangement is acquired productively.[11]-[16]

The Abaqus finite element system includes:

- Abaqus/Standard, a universally useful limited component program

- Abaqus/Explicit, an unequivocal elements limited component program

- Abaqus/CFD, a broadly useful computational liquid elements program

- Abaqus/CAE, an intelligent domain used to make limited component models, submit Abaqus investigations, screen and analyze occupations, and assess results

- Abaqus/Viewer, a subset of Abaqus/CAE that contains just the post handling abilities of the Visualization module.

The limited component program of ABAQUS/Standard 6.12 rendition is utilized to build up the limited component model, which meant to recreate the conduct of the virus shaped pressure individuals with web gaps under pivotal pressure.

\section{SECTION GEOMETRY}

Cold shaped steel channel segment having distinctive geometry as appeared in Fig. 3.5 were proposed by various thinness proportion, rib width and thickness. This guarantees the examination of pressure individuals is to be conveyed for a wide range of sections (for example short, middle of the road and long section). In this work channel area with halfway and complex edge stiffeners with web gaps were created. The thickness of area embraced as $1 \mathrm{~mm}$ and $2 \mathrm{~mm}$. Table 3.1 shows measurements of the area and their characterization.

Table 1 Geometric Details of Specimen[17]-[22]

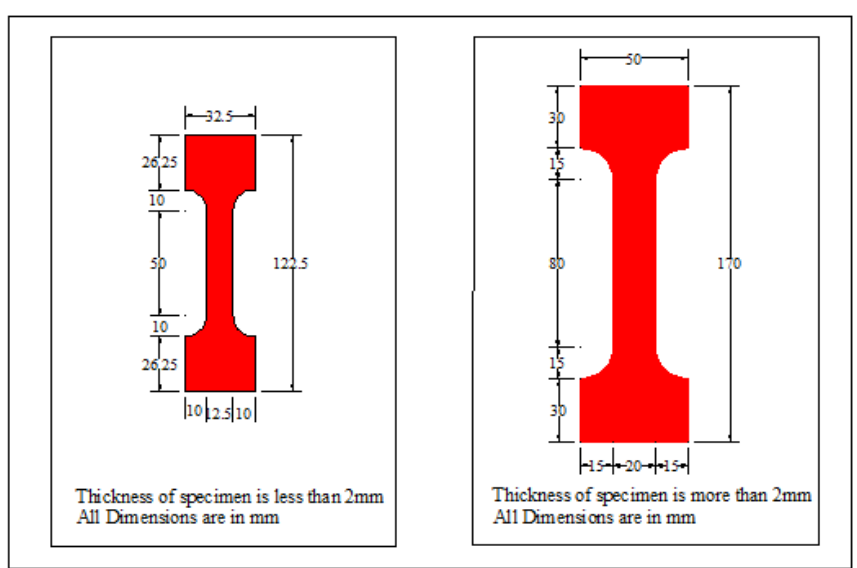

Table 1 Geometric Details of Specimen

\begin{tabular}{|c|c|c|c|c|c|}
\hline $\begin{array}{l}\text { S1. } \\
\text { No. }\end{array}$ & Type & $\begin{array}{l}\text { Cross } \\
\text { Section } \\
\text { Type }\end{array}$ & $\begin{array}{l}\text { Length } \\
\text { (mm) }\end{array}$ & $\begin{array}{c}\text { Thickness } \\
\text { (mm) }\end{array}$ & Designation \\
\hline 1 & \multirow{4}{*}{$\begin{array}{l}\text { Short } \\
\text { Column }\end{array}$} & $\mathrm{Cl}$ & 700 & 1 & C1L700t1 \\
\hline 2 & & $\mathrm{Cl}$ & 700 & 2 & C1L 700t2 \\
\hline 3 & & $\mathrm{C} 2$ & 700 & 1 & C2L700t1 \\
\hline 4 & & $\mathrm{C}_{2}$ & 700 & 2 & $\mathrm{C} 2 \mathrm{~L} 700 \mathrm{t} 2$ \\
\hline 5 & \multirow{4}{*}{$\begin{array}{c}\text { Intermediate } \\
\text { Column }\end{array}$} & $\mathrm{Cl}$ & 1250 & 1 & C1L 1250t1 \\
\hline 6 & & $\mathrm{Cl}$ & 1250 & 2 & C1L $1250 t 2$ \\
\hline 7 & & $\mathrm{C} 2$ & 1250 & 1 & C2L1250tl \\
\hline 8 & & $\mathrm{C}_{2}$ & 1250 & 2 & $\mathrm{C} 2 \mathrm{~L} 1250 \mathrm{t} 2$ \\
\hline 9 & \multirow{4}{*}{$\begin{array}{l}\text { Long } \\
\text { Column }\end{array}$} & $\mathrm{Cl}$ & 1800 & 1 & C1L1800t1 \\
\hline 10 & & $\mathrm{Cl}$ & 1800 & 2 & C1L1800t2 \\
\hline 11 & & $\mathrm{C}_{2}$ & 1800 & 1 & C2L1800tl \\
\hline 12 & & $\mathrm{C} 2$ & 1800 & 2 & $\mathrm{C} 2 \mathrm{~L} 1800 \mathrm{t} 2$ \\
\hline
\end{tabular}

Figure 2 Geometric Details of Specimen
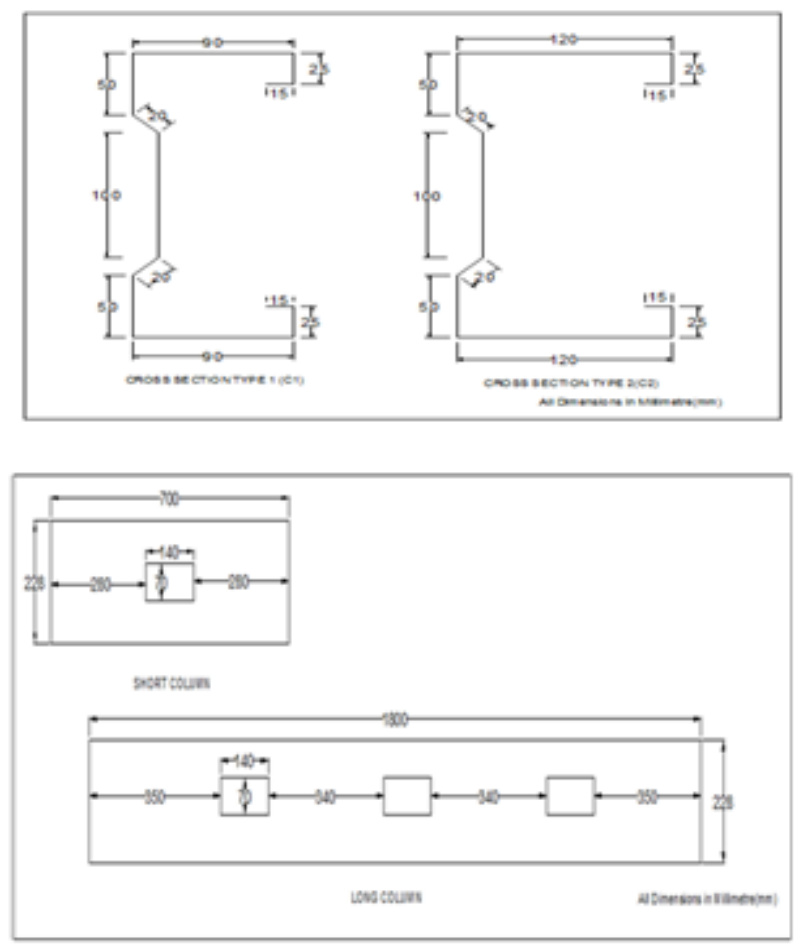

Figure 3 Dimensions of Coupon

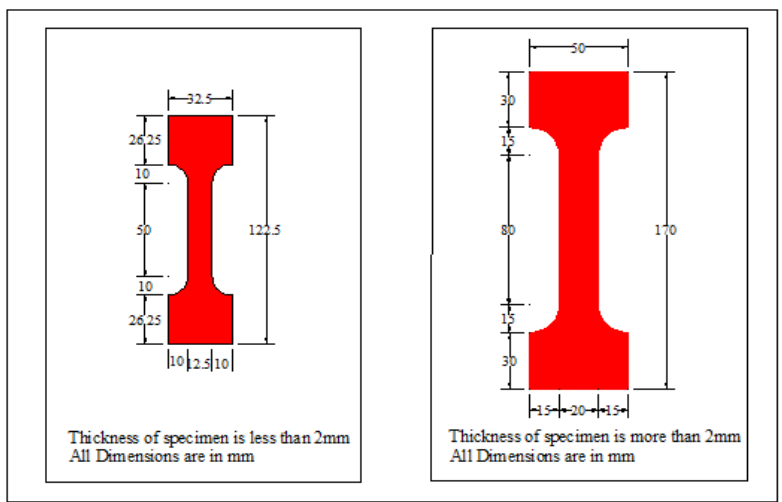

Figure 4 Geometric Details of Specimen 


\section{A. MATERIAL PROPERTIES}

Cold shaped steel channel segment having distinctive geometry as appeared in Fig. 3.5 were proposed by various thinness proportion, rib width and thickness. This guarantees the examination of pressure individuals is to be conveyed for a wide range of sections (for example short, middle of the road and long section). In this work channel area with halfway and complex edge stiffeners with web gaps were created. The thickness of area embraced as $1 \mathrm{~mm}$ and $2 \mathrm{~mm}$. Table 3.1 shows measurements of the area and their characterization.[23]-[34]

The table 3.2 shows the yield stress of different thickness specimens and table 3.3 shows the stress and strain values.

Table 2 Coupon Test Results

\begin{tabular}{|c|c|c|c|c|}
\hline $\begin{array}{c}\text { Specimen } \\
\text { Details }\end{array}$ & $\begin{array}{c}\text { Yield } \\
\text { Load } \\
(\mathrm{kN})\end{array}$ & $\begin{array}{c}\text { Ultimate } \\
\text { Load } \\
(\mathrm{kN})\end{array}$ & $\begin{array}{c}\text { Yield Stress } \\
\left(\mathrm{N} / \mathrm{mm}^{2}\right)\end{array}$ & $\begin{array}{c}\% \text { of } \\
\text { Elongation }\end{array}$ \\
\hline $\mathrm{S} 1(1.2 \mathrm{~mm})$ & 3.8 & 5 & 253 & 16.30 \\
\hline $\mathrm{S} 2(2 \mathrm{~mm})$ & 8.4 & 12.8 & 220 & 18.23 \\
\hline
\end{tabular}

Table 3. Nominal \& True Stress and Strain

\begin{tabular}{|c|c|c|c|}
\hline $\begin{array}{c}\text { Nominal Stress } \\
\left(\mathbf{N} / \mathbf{m m}^{\mathbf{2}}\right)\end{array}$ & $\begin{array}{c}\text { Nominal } \\
\text { strain }\end{array}$ & $\begin{array}{c}\text { True Stress } \\
\left(\mathbf{N} / \mathbf{m m}^{\mathbf{2}}\right)\end{array}$ & Plastic Stain \\
\hline 0 & 0 & - & - \\
\hline 200 & 0.00095 & 200.2 & 0 \\
\hline 240 & 0.025 & 246 & 0.02374 \\
\hline 280 & 0.050 & 294 & 0.04784 \\
\hline 340 & 0.100 & 374 & 0.09436 \\
\hline 380 & 0.150 & 437 & 0.1388 \\
\hline 400 & 0.200 & 480 & 0.1814 \\
\hline
\end{tabular}

\section{DEVELOPMENT OF MODEL IN ABAQUS}

\section{A. CHOICE OF ELEMENT TYPE}

ABAQUS has several element types suitable for numerical analysis: two or three dimensional solid elements, membrane and truss elements, beam elements, and shell elements are some of them. The primary aim of this analysis was to understand the different buckling failure modes of CFS Column members. The 4-noded shell elements can be used efficiently to model this type of column geometries.

Therefore the most appropriate element type to model CFS column sections for the behavior is shell element and they were used in all the finite element models.

\section{B. MODELLING AND MESHING}

The Modelling of cold formed steel column was started by creating three dimensional, deformable, Shell shape and extrusion type part in ABAQUS. The Geometry of the cold formed steel column profiles as shown in figure 3.8 was sketched. The shell element was used in all the finite element models. Finite element models simulating the boundary conditions similar to UTM support conditions (i.e. One end is fixed and other end is free to translate in one direction) and axial compression were developed. Free meshing of the model was carried out. The minimum size of the mesh kept as $10 \mathrm{~mm}$. The figure $3.8-3.10$ shows the Modelling and Meshing of cold formed steel compression members.

\section{BOUNDARY CONDITIONS:}

The objective of ideal finite element models was to provide support conditions similar to UTM Supports (One end is fixed and other end is free to translate in loading direction) and to study their flexural behavior. Boundary conditions implemented in the Finite Element model are described as follows:

1. Encastre at one end was modelled by restraining all degree of freedom. $\left(\mathbf{U}_{\mathbf{1}}=\mathbf{U}_{\mathbf{2}}=\mathbf{U}_{\mathbf{3}}=\mathbf{U} \mathbf{R}_{\mathbf{1}}=\mathbf{U} \mathbf{R}_{\mathbf{2}}=\mathbf{U R} \mathbf{\mathbf { R } _ { 3 }}=\mathbf{0}\right)$

2. Y-Axisymmetric at other end modelled by restraining translation in translation and rotation in two directions only. $\left(\mathbf{U}_{1}=\mathbf{U}_{3}=\mathbf{U R}_{2}=\mathbf{0}\right)$

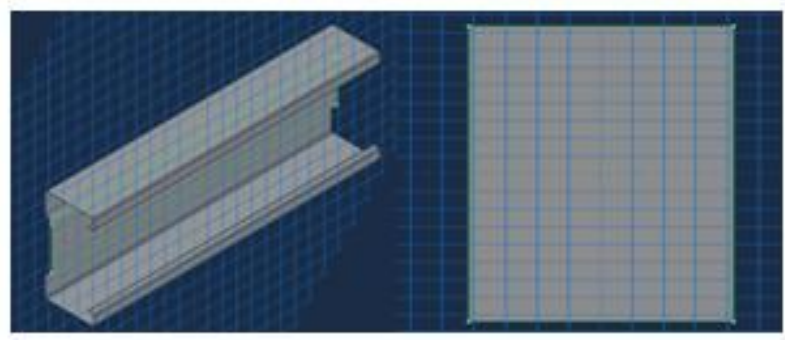

Figure 5 CFS Column Profile view (Part 1 \& Part 2)

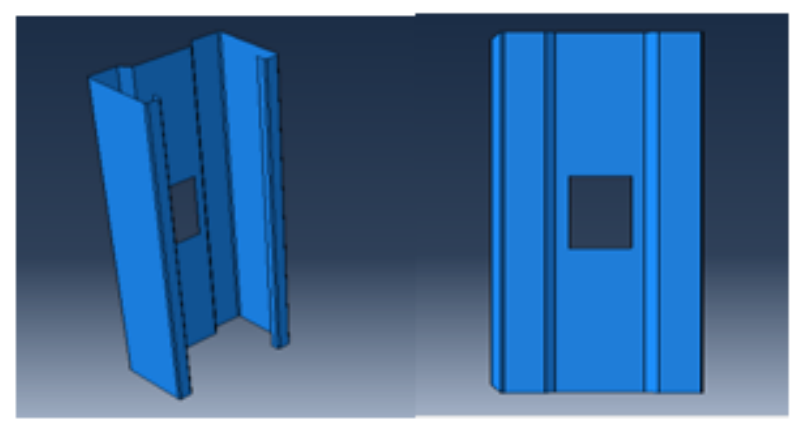

Figure 6 CFS Column in Assembly View 
Finite Element Analysis of Cold Formed Steel Channel Columns with Complex Edge Stiffeners and Web Holes using Abaqus

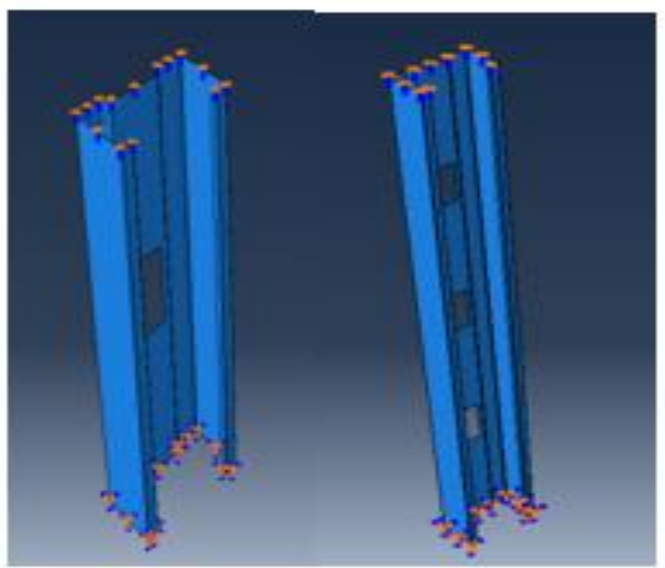

Shell edge load was applied at the top of compression member on all elements. The entire load is distributed uniformly along negative Y-direction and normal traction per unit deformed area. The loads were applied in increments. The initial increment size was kept as 0.1 . The maximum increment size was kept as 1.0 and minimum increment size was kept as 0.00001. A Static, Riks analysis was carried out to analyse the member. The Nlgeom (Nonlinear geometry) is switched on during analysis.

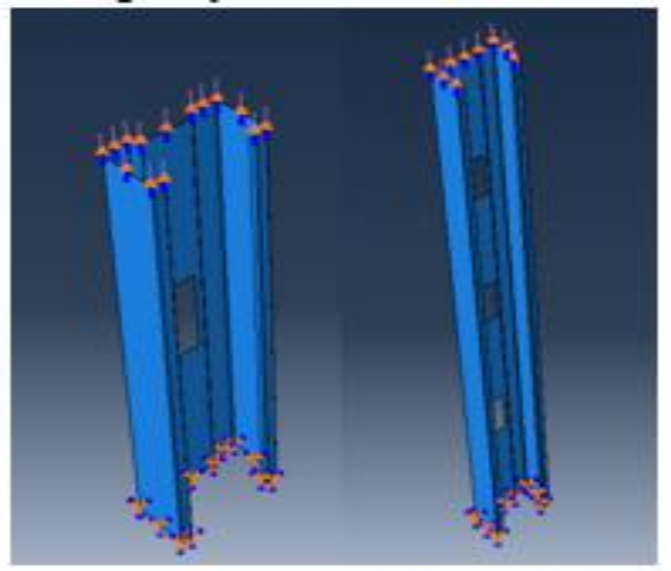

Figure 7,8 Loading Pattern and View

\section{RESULTS AND DISCUSSION}

\section{A. COMPARISON OF ULTIMATE LOAD OF VARIOUS COLUMN}

The Table shows the ultimate load variation and buckling mode for various column type and various cross section. The results shows that the short coulmn fails mainly by local and distortional buckling and intermediate \& long column shows local, distortional and flexural buckling.

\begin{tabular}{|c|c|c|c|c|}
\hline $\begin{array}{l}\text { Sl. } \\
\text { No. }\end{array}$ & $\begin{array}{c}\text { Column } \\
\text { Type }\end{array}$ & Designation & $\begin{array}{c}\text { Ultimate } \\
\text { Load in } \\
\mathrm{kN}\end{array}$ & $\begin{array}{c}\text { Buckling } \\
\text { mode }\end{array}$ \\
\hline 1 & \multirow{4}{*}{$\begin{array}{c}\text { Short } \\
\text { Column }\end{array}$} & C1L700T1 & 60.5 & $\mathrm{~L}+\mathrm{D}$ \\
\hline 2 & & C1L700T2 & 151.3 & $\mathrm{~L}+\mathrm{D}$ \\
\hline 3 & & $\mathrm{C} 2 \mathrm{~L} 700 \mathrm{~T} 1$ & 51.085 & $\mathrm{~L}+\mathrm{D}$ \\
\hline 4 & & $\mathrm{C} 2 \mathrm{~L} 700 \mathrm{~T} 2$ & 174.3 & $\mathrm{~L}+\mathrm{D}$ \\
\hline 5 & \multirow{4}{*}{$\begin{array}{l}\text { Long } \\
\text { Column }\end{array}$} & C1L1800T1 & 40.2 & $\mathrm{~L}+\mathrm{D}+\mathrm{F}$ \\
\hline 6 & & C1L1800T2 & 139.577 & $\mathrm{~L}+\mathrm{D}+\mathrm{F}$ \\
\hline 7 & & C2L1800T1 & 39.1 & $\mathrm{~L}+\mathrm{D}+\mathrm{F}$ \\
\hline 8 & & $\mathrm{C} 2 \mathrm{~L} 1800 \mathrm{~T} 2$ & 159.8 & $\mathrm{~L}+\mathrm{D}+\mathrm{F}$ \\
\hline
\end{tabular}

\section{B. LOAD VS DEFLECTION RESUTS}

The Table shows the load vs deflection for short column of cross section 1 and thickness $1 \mathrm{~mm}$. the rotational displacement is taken for direction 3. (UR3

\begin{tabular}{|c|c|c|c|c|c|}
\hline \multirow{2}{*}{$\begin{array}{c}\text { Sl. } \\
\text { No. }\end{array}$} & Load & \multicolumn{4}{|c|}{ Displacement in mm } \\
\cline { 3 - 6 } & in & U1 & U2 & U3 & UR3 \\
\hline 1 & 0 & 0 & 0 & 0 & 0 \\
\hline 2 & 5 & -0.04 & -0.01 & -0.01 & 0 \\
\hline 3 & 10 & -0.08 & -0.03 & -0.01 & 0 \\
\hline 4 & 15 & -0.14 & -0.05 & -0.02 & 0.00009 \\
\hline 5 & 20 & -0.17 & -0.07 & -0.02 & 0.00013 \\
\hline 6 & 25 & -0.25 & -0.09 & -0.03 & 0.00018 \\
\hline 7 & 30 & -0.29 & -0.11 & -0.03 & 0.00021 \\
\hline 8 & 35 & -0.33 & -0.13 & -0.04 & 0.00025 \\
\hline 9 & 40 & -0.4 & -0.15 & -0.04 & 0.00031 \\
\hline 10 & 45 & -0.46 & -0.16 & -0.03 & 0.00068 \\
\hline 11 & 50 & -0.78 & -0.17 & -0.01 & 0.0016 \\
\hline 12 & 55 & -1.9 & -0.19 & 0.18 & 0.0129 \\
\hline 13 & 60 & -3.5 & -0.2 & 0.38 & 0.0298 \\
\hline 14 & 60.5 & -3.93 & -0.21 & 0.43 & 0.0338 \\
\hline 15 & 55 & -4.5 & -0.24 & 0.55 & 0.0406 \\
\hline 16 & 50 & -7.2 & -0.52 & 1.31 & 0.0785 \\
\hline 17 & 40 & -14.54 & -1.34 & 2.64 & 0.1368 \\
\hline 18 & 30 & -14.54 & -2.56 & 1.91 & 0.1946 \\
\hline 19 & 20 & -31.35 & -7.5 & 6.68 & 0.3624 \\
\hline 20 & 13.5 & -33.58 & -13.9 & 15.55 & 0.4814 \\
\hline & & & & & \\
\hline
\end{tabular}

\section{SHORT COLUMN}

The Figure 4.1 shows the Load vs Deflection behavior of short column of different cross section $(\mathrm{C} 1, \mathrm{C} 2)$ and different thickness (1mm, 2mm)

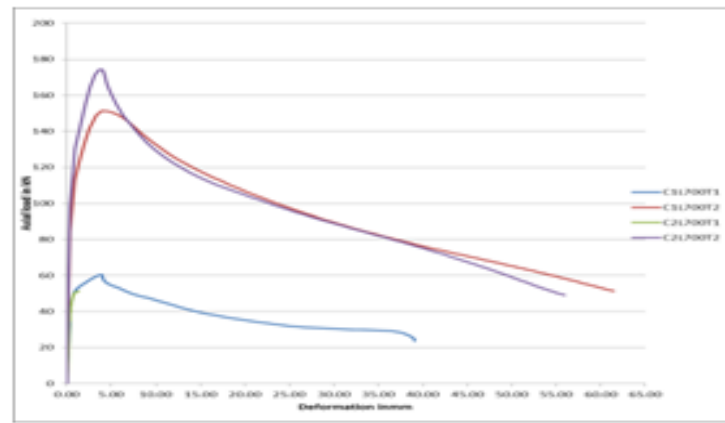

Fig 9:Load vs Deflection 


\section{LONG COLUMN}

The Figure 4.1 shows the Load vs Deflection behavior of long column of different cross section ( 1 1 \& $\mathrm{C} 2)$ and different thickness (1mm and $2 \mathrm{~mm})$

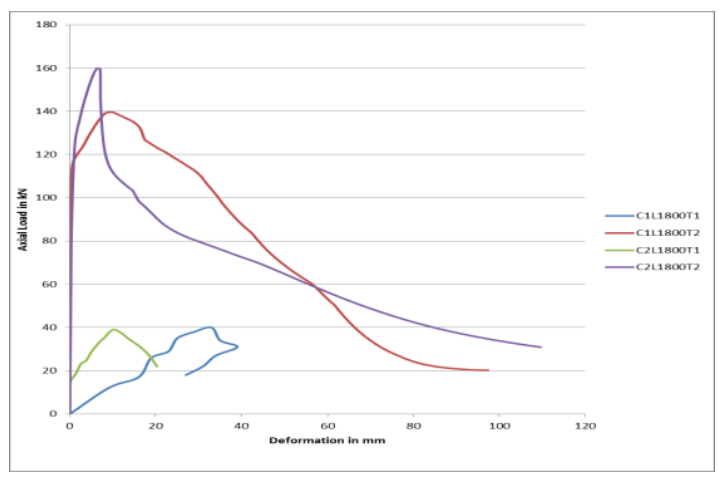

Fig 10:Load vs Deflection

\section{E. DEFORMATION PROFILES}

The Figure 11 and 12 shows the deformed profiles and Undeformed profiles of critical sections
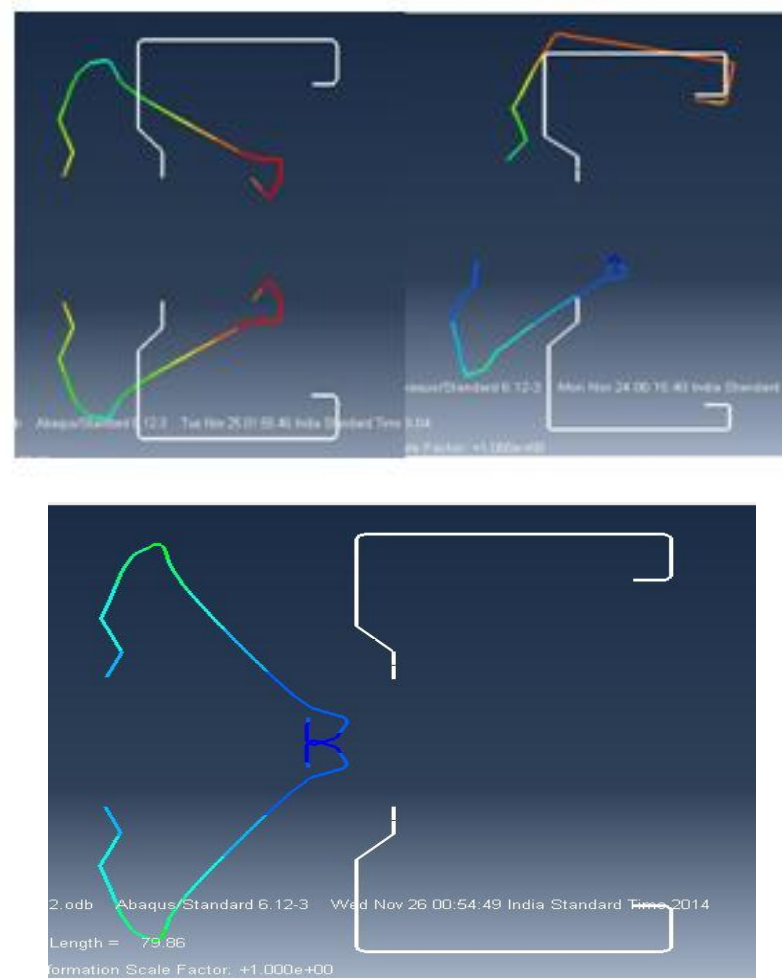

Figure 13 Deformed Shape of C2L1800T2

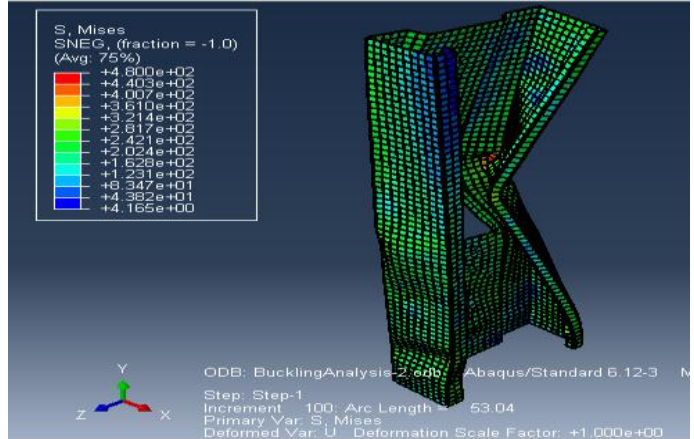

\section{DEFORMATION SHAPES}

Retrieval Number: K128610812S19 /2019@BEIESP DOI: 10.35940/ijitee.K1286.10812S19
The Deformation shape of C1L700T1 and C2L700T2 areshown in Fig 14

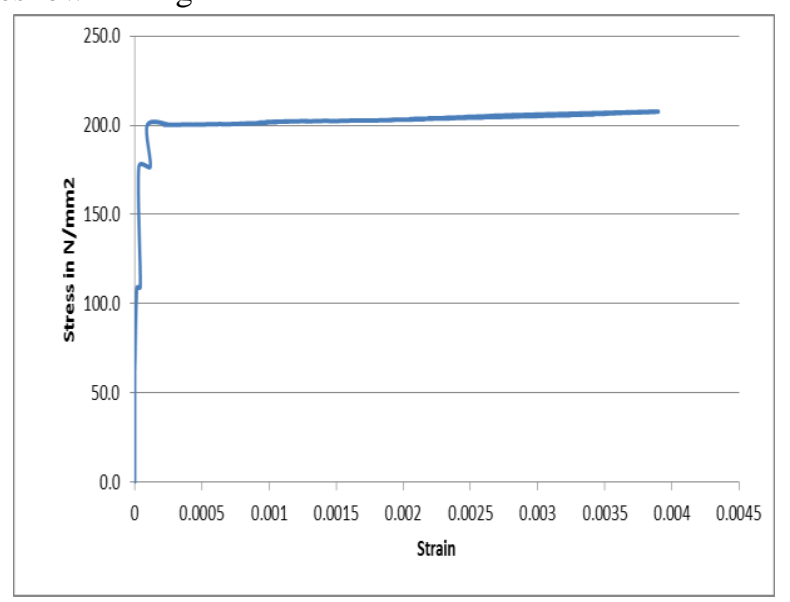

\section{CONCLUSIONS}

The accompanying ends are produced using logical examination of channel segment with middle and edge stiffeners with web openings utilizing ABAQUS v6.12.3.

$\square$ a definitive heap of channel area section with complex edge stiffeners and middle stiffeners is found by utilizing ABAQUS v6.14-2 by Static, Riks Method.

a definitive heap of channel segment section with complex edge stiffeners and halfway stiffeners with web gaps relies upon the thickness to width proportion of the plates.

$\square$ The conveying proficiency will be higher as the thickness width proportion expanding.

$\square$ The fundamental disappointment method of channel segment with stiffeners and web gaps is distortional clasping. The flexural clasping is relies upon length of the models.

$\square$ The web openings having noteworthy effect on pressure appropriation. Since the holes on the web, the situation of most extreme pressure changes from the web close to the mid stature of the examples to the area of the adjoining openings.

\section{REFERENCES}

1. Iyappan L., Dayakar P., Identification of landslide prone zone for coonoortalukusing spatial technology, International Journal of Applied Engineering Research,V-9,I-22,PP-5724-5732,Y-2014.

2. Kumar J., Sathish Kumar K., Dayakar P.,Effect of microsilica on high strength concrete, International Journal of Applied Engineering Research,V-9,I-22,PP-5427-5432,Y-2014

3. Dayakar P., Vijay Ruthrapathi G., Prakesh J., Management of bio-medical waste, International Journal of Applied Engineering Research,V-9,I-22,PP-5518-5526,Y-2014.

4. Swaminathan N., Dayakar P., Resource optimization in construction project, International Journal of Applied Engineering Research,V-9,I-22,PP-5546-5551,Y-2014.

5. Venkat Raman K., Dayakar P., Raju K.V.B.,An experimental study on effect of cone diameters in penetration test on sandy soil, International Journal of Civil Engineering and Technology,V-8,I-8,PP-1581-1588,Y-2017. 
6. Saritha B., Chockalingam M.P.,Photodradation of malachite green DYE using TIO2/activated carbon composite,International Journal of Civil Engineering and Technology,V-8,I-8,PP-156-163,Y-2017

7. Shendge R.B., Chockalingam M.P., Saritha B., Ambica A.,Swat modelling for sediment yield: A case study of Ujjani reservoir in Maharashtra, India,International Journal of Civil Engineering and Technology,V-9,I-1,PP-245-252,Y-2018

8. Chockalingam M.P., Balamurgan V.,Modernisation of an existing urban road-sector in Chennai, a case study report,International Journal of Civil Engineering and Technology,V-8,I-8,PP-1457-1467,Y-2017

9. Saritha B., Chockalingam M.P.,Adsorption study on removal of basic dye by modified coconut shell adsorbent, International Journal of Civil Engineering and Technology,V-8,I-8,PP-1370-1374,Y-2017

10. Saritha B., Chockalingam M.P.,Adsorptive removal of heavy metal chromium from aqueous medium using modified natural adsorbent,International Journal of Civil Engineering and Technology,V-8,I-8,PP-1382-1387,Y-2017

11. Chockalingam M.P., Palanivelraja S.,Retrospective analysis of a theoretical model used for forecasting future air quality near the north Chennai thermal power plant,International Journal of Civil Engineering and Technology,V-8,I-8,PP-1457-1467,Y-2017

12. Saritha B., Chockalingam M.P.,Photodegradation of methylene blue dye in aqueous medium by $\mathrm{Fe}-\mathrm{AC} / \mathrm{TiO} 2$ Composite,Nature Environment and Pollution Technology,V-17,I-4,PP-1259-1265,Y-2018

13. Shendge R.B., Chockalingam M.P., Kaviya B., Ambica A.,Estimates of potential evapotranspiration rates by three methods in upper Bhima Basin, In Maharashtra, India,International Journal of Civil Engineering and Technology,V-9,I-2,PP-475-480,Y-2018

14. Shendge R.B., Chockalingam M.P.,The soil and water assessment tool for Ujjani Reservoir,International Journal of Mechanical Engineering and Technology,V-9,I-2,PP-354-359,Y-2018

15. Shendge R.B., Chockalingam M.P.,A review on soil and water assessment tool,International Journal of Mechanical Engineering and Technology,V-9,I-2,PP-347-353,Y-2018

16. Sachithanandam P., Meikandaan T.P., Srividya T.,Steel framed multi storey residential building analysis and design,International Journal of Applied Engineering Research,V-9,I-22,PP-5527-5529,Y-2014

17. Meikandaan T.P., Ramachandra Murthy A.,Study of damaged RC beams repaired by bonding of CFRP laminates,International Journal of Civil Engineering and Technology,V-8,I-2,PP-470-486,Y-2017

18. Meikandaan T.P., Ramachandra Murthy A.,Retrofittng of reinforced concrete beams using GFRP overlays,International Journal of Civil Engineering and Technology,V-8,I-2,PP-423-439,Y-2017

19. Meikandaan T.P., Ramachandra Murthy A.,Flexural behaviour of RC beam wrapped with GFRP sheets,International Journal of Civil Engineering and Technology,V-8,I-2,PP-452-469,Y-2017

20. Meikandaan T.P., Murthy A.R.,Experimental study on strengthening of rc beams using glass Fiber,International Journal of Civil Engineering and Technology,V-9,I-11,PP-959-965,Y-2018

21. Meikandaan T.P., Hemapriya M.,Use of glass FRP sheets as external flexural reinforcement in RCC Beam,International Journal of Civil Engineering and Technology,V-8,I-8,PP-1485-1501,Y-2017

22. Saraswathy R., Saritha B.,Planning of integrated satellite township at Thirumazhisai,International Journal of Applied Engineering Research,V-9,I-22,PP-5558-5560,Y-2014

23. Saritha B., Ilayaraja K., Eqyaabal Z.,Geo textiles and geo synthetics for soil reinforcement,International Journal of Applied Engineering Research,V-9,I-22,PP-5533-5536,Y-2014

24. Ambica A., Saritha B., Changring G., Singh N B., Rajen M., Salman Md.,Analysis of groundwater quality in and around Tambaram taluk, Kancheepuram district,International Journal of Civil Engineering and Technology,V-8,I-8,PP-1362-1369,Y-2017

25. Arunya A., Sarayu K., Ramachandra Murthy A., Iyer N.R.,Enhancement of durability properties of bioconcrete incorporated with nano silica,International Journal of Civil Engineering and Technology,V-8,I-8,PP-1388-1394,Y-2017

26. Ilayaraja K., Krishnamurthy R.R., Jayaprakash M., Velmurugan P.M., Muthuraj S.,Characterization of the 26 December 2004 tsunami deposits in Andaman Islands (Bay of Bengal, India),Environmental Earth Sciences,V-66,I-8,PP-2459-2476,Y-2012

27. Ilayaraja K.,Morphometric parameters of micro watershed in Paravanar sub-basin, Cuddalore District,International Journal of Civil Engineering and Technology,V-8,I-8,PP-1444-1449,Y-2017

28. Ilayaraja K., Singh R.K., Rana N., Chauhan R., Sutradhar N.,Site suitability assessment for residential areas in south Chennai region using remote sensing and GIS techniques,International Journal of Civil Engineering and Technology,V-8,I-8,PP-1468-1475,Y-2017

29. Ilayaraja K., Reza W., Kumar V., Paul S., Chowdhary R.,Estimation of land surface temperature of Chennai metropolitan area using Landsat images, International Journal of Civil Engineering and Technology,V-8,I-8,PP-1450-1456,Y-2017

30. Chitra R.,Experimental study on beam using steel fiber and latex,International Journal of Civil Engineering and Technology,V-8,I-8,PP-1395-1403,Y-2017

31. Chitra R.,Analysis of traffic and management at Kovilambakkam intersection,International Journal of Civil Engineering and Technology,V-8,I-8,PP-1433-1443,Y-2017

32. Aswathy M.,Experimental study on light weight foamed concrete,International Journal of Civil Engineering and Technology,V-8,I-8,PP-1404-1412,Y-2017

33. Aswathy M.,Wastewater treatment using constructed wetland with water lettuce (Eichornia Crasipies),International Journal of Civil Engineering and Technology,V-8,I-8,PP-1413-1421,Y-2017

34. Kiruthiga K., Anandh K.S., Gunasekaran K, Assessment of influencing factors on improving effectiveness and productivity of construction engineers, 2015, International Journal of Applied Engineering Research, V - 10,I -17,p -13849-13854.

\section{AUTHORS PROFILE}

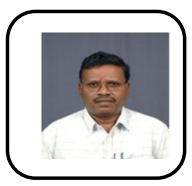

Dr.A.Mani, Professor, Department Of Civil Engineering,,Bharath Institution Of Higher Education And Research,TamilNadu, India

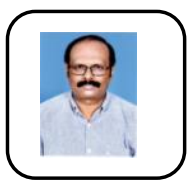

Justin Jagadeep Kumar Student,Department Of Civil Engineering,,Bharath Institution Of Higher Education And Research,TamilNadu, India 